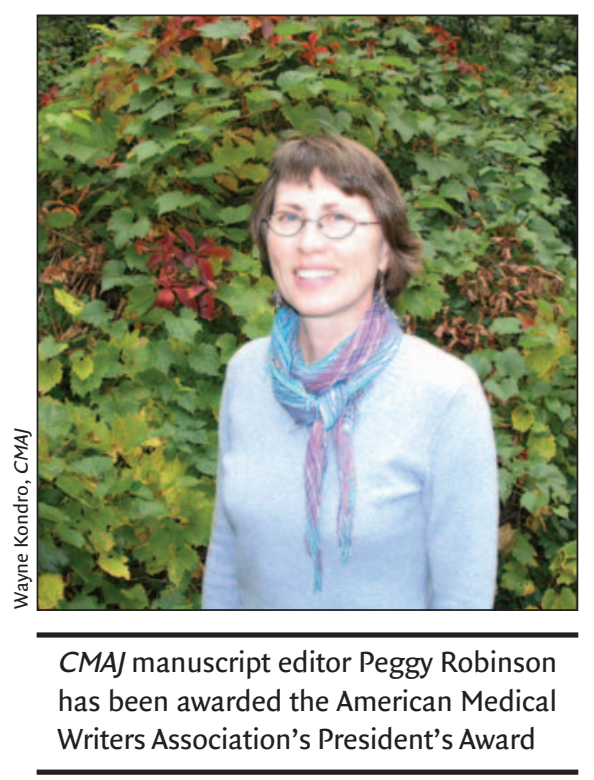

AMWA Honour: The American Medical Writers Association will this year confer its prestigious President's Award on Peggy Robinson, CMAF's former manager of submissions and peer review, and former managing editor. Robinson was "honoured" to receive the award, which was established in I940 to improve the quality of medical communication. "AMWA provides a top-notch educational program for biomedical communications through its high quality, hands-on workshops." In addition to serving as treasurer of the association's Canada Chapter for I4 years, Robinson has been actively involved in organizing and presenting non-credit workshops and conferences. She continues to serve on the association's budget and finance committee, while working as a freelance manuscript editor at CMAJ. - Shawna Lessard, Ottawa

Heading west: Alberta has supplanted $\mathrm{BC}$ as the El Dorado of the health care profession as it attracted more health care providers than any other province between 1996 and 200I, according to the Canadian Institute for Health Information. Alberta's health workforce rose $4 \%$ over that 5 -year period as the province assumed the mantle as the nation's preferred work destination, held for Io years by British Columbia. Compiled by Wayne Kondro, CMAJ
Pulse

\section{Differences in healthy life}

expectancy among men and

\section{women}

$\checkmark$ he World Health Organization (WHO) defines healthy life expectancy as the "average number of years that a person can expect to live in 'full health' by taking into account years lived in less than full health due to disease and/or injury." Figure I shows the most recent WHO data on healthy life expectancies for 23 countries. ${ }^{1}$

On average, women tend to live longer than men. This trend also applies to healthy life expectancy in most countries. However, there are several exceptions. Figure I shows the 8 coun- tries where the difference in healthy life expectancy is greatest in favour of men and the 8 countries where the difference is greatest in favour of women as well as the $\mathrm{G}_{7}$ countries for comparison. In Canada, the healthy life expectancy for women is 4 years longer than for men. The most striking exception to the general trend is Qatar, where men live in "full health" an average of 2.9 years longer than women. Russia is at the other end of the spectrum, where men are affected by major illness or injury II years before women. - Mark O. Baerlocher MD, Toronto

\section{REFERENCE}

I. World Health Statistics 2007. Geneva: World Health Organization; 2007. Available: www.who.int/whosis /whostat2007/en/index.html (accessed 2007 Sept I9).

DOI:Io.I503/cmaj.060674

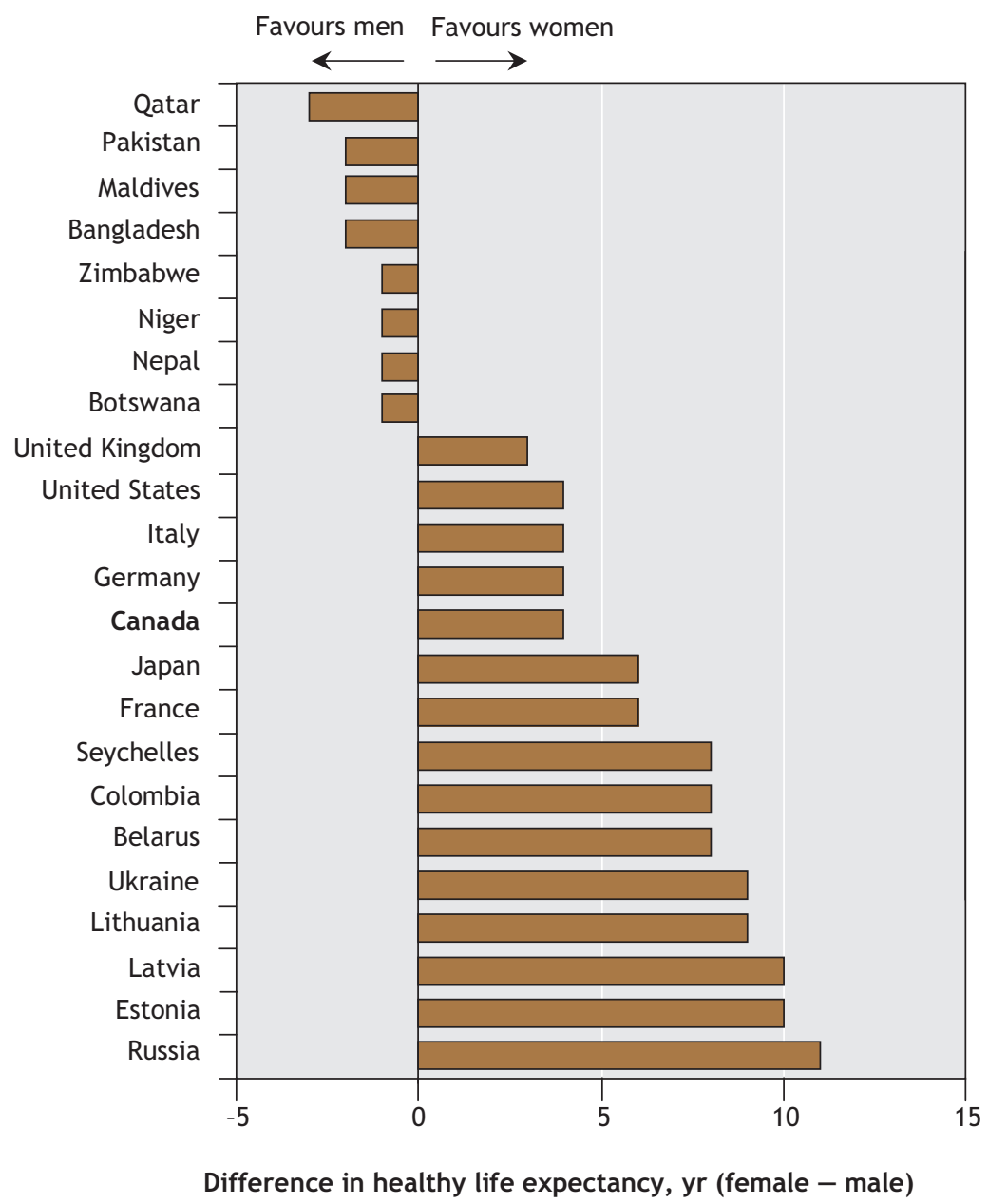

Figure 1: Differences in healthy life expectancy by sex. 